\title{
EPIDEMIOLOGY OF ANTERIOR CRUCIATE LIGAMENT RECONSTRUCTION IN BRAZIL'S PUBLIC HEALTH SYSTEM
}

Original Article

ARtigo ORIGINAL Artículo Original

\author{
EPIDEMIOLOGIA DA RECONSTRUÇÃO DO LIGAMENTO CRUZADO ANTERIOR NO SISTEMA \\ PÚBLICO DE SAÚDE DO BRASIL
}

\author{
EPIDEMIOLOGÍA DE LA RECONSTRUCCIÓN DEL LIGAMENTO CRUZADO ANTERIOR \\ EN EL SISTEMA DE SALUD PÚBLICA DE BRASIL
}

\begin{abstract}
Thiago Jambo Alves Lopes ${ }^{1,2}$ (Physiotherapy)

Milena Simic ${ }^{1}$ (Physiotherapy)

Evangelos Pappas ${ }^{1,3}$ (Physiotherapy)

1. University of Sydney, Faculty of Health Sciences, Discipline of Physiotherapy Sydney, Australia 2. Research Laboratory of Exercise Science, The Brazilian Navy, Av. Brasil 10590 - Penha, Postcode: 21012-351, Rio de Janeiro, Brazil.

3. University of Ioannina, School of Medicine, Department of Orthopaedic Surgery, loannina, Orthopaedic and Sports Medicine Center, Greece
\end{abstract}

\section{Correspondence:}

Discipline of Physiotherapy, Faculty of Health Sciences, The University of Sydney. Cumberland Campus, S Block, 75 East Street, Lidcombe NSW 2141, Australia.

tjam7956@uni.sydney.edu.au

\begin{abstract}
Introduction: Several studies have reported on the epidemiology of Anterior Cruciate Ligament Reconstruction (ACLR) in Europe and North America; however, there is currently no data relating to Brazil. Objective: To describe the incidence of ACLR in Brazil and investigate temporal trends and differences between age and sex groups. Methods: All reported ACLR cases in the public hospital system between January 2008 and December 2014 were extracted from the Information Technology Department of the Brazilian Ministry of Health. Linear regression analysis was used to assess changes in ACLR incidence in the overall population and among sex and age groups, hospitalization time, and health care costs. Results: A total of 48,241 ACLR were reported from 2008-2014 with an overall incidence of 3.49 per 100,000 persons/year. Males accounted for $82 \%$ of the procedures. The incidence of ACLR increased by $56 \%$ among males $(p=0.01)$ and by $112 \%$ among females ( $p=0.001$ ). The mean hospitalization time decreased from 2.4 days in 2008 to 1.8 day in 2014 $\left(R^{2}=0.883, p=0.002\right)$. The total cost across all years was US\$56 million, with a mean of US\$1,145 per ACLR. Conclusion: Although the total incidence of ACLR in Brazil is lower compared to other countries, it has increased over the years, especially in females. The creation of an ACLR registry is necessary in the future, for more accurate control and new investigations.
\end{abstract}

Keywords: anterior cruciate ligament reconstruction; incidence; sex; age groups.

\section{RESUMO}

Introdução: Vários estudos têm relatado a epidemiologia da reconstrução do ligamento cruzado anterior (RLCA) na Europa e América do Norte, no entanto, não há atualmente dados referentes ao Brasil. Objetivo: Descrever a incidência de RLCA no Brasil e investigar tendências temporais e diferenças entre os grupos de idade e sexo. Métodos: Todos os casos relatados de RLCA no sistema público de saúde do Brasil entre janeiro de 2008 e dezembro 2014 foram extraídos do Departamento de Informática do Ministério da Saúde do Brasil. A análise de regressão linear foi usada para avaliar as mudanças na incidência de RLCA na população total e entre grupos de sexo e idade, tempo de internação e custos hospitalares. Resultados: Um total de 48,241 RLCA foi reportado entre 2008 e 2014, com incidência geral de 3,49 por 100.000 pessoas/ano. Homens foram responsáveis por 82\% dos procedimentos. A incidência de RLCA aumentou 56\% entre os homens $(p=0,01)$ e 112\% entre as mulheres $(p=0,001)$. O tempo médio de permanência hospitalar diminuiu de 2,4 dias em 2008 para 1,8 dia em 2014 $\left(R^{2}=0,883, p=0,002\right)$. O custo total em todos os anos foi de US\$56 milhões, com média de US\$1.145 por RLCA. Conclusão: Apesar da incidência total de RLCA no Brasil ser menor em comparação com outros países, ela tem aumentado ao longo dos anos, principalmente em mulheres. A criação de um registro de RLCA se faz necessária no futuro para um controle mais acurado e novas investigações.

Descritores: reconstrução do ligamento cruzado anterior; incidência; sexo; grupos etários.

\section{RESUMEN}

Introducción: Diversos estudios han informado sobre la epidemiología de la reconstrucción del ligamento cruzado anterior (RLCA) en Europa y América del Norte, sin embargo, no hay actualmente datos relativos a Brasil. Objetivo: Describir la incidencia de la RLCA en Brasil e investigar las tendencias temporales y diferencias entre los grupos de edad y sexo. Métodos: Todos los casos reportados de RLCA en el sistema de salud pública en Brasil entre enero de 2008 y diciembre de 2014 fueron extraídos del Departamento de Informática del Ministerio de Salud de Brasil. Se utilizó un análisis de regresión lineal para evaluar los cambios en la incidencia de RLCA en la población total y entre los grupos de edad y sexo, duración de la estancia hospitalaria y los costes de hospitalización. Resultados: Un total de 48.241 reconstrucciones del LCA fue reportado entre 2008 y 2014, con una incidencia general de 3,49 por 100.000 personas/año. Los hombres representaron el 82\% de los procedimientos. La incidencia de RLCA aumentó $56 \%$ en los hombres $(p=0,01)$ y $112 \%$ en las mujeres $(p=0,001)$. La duración media 
de la estancia hospitalaria se redujo de 2,4 días en 2008 a 1,8 día en $2014\left(R^{2}=0,883, p=0,002\right)$. El coste total en todos los años fue de US\$ 56 millones, con un promedio de US\$1.145 para cada RLCA. Conclusión: Aunque la incidencia global de RLCA en Brasil sea más pequeña en comparación con otros países, se ha incrementado en los últimos años, especialmente en las mujeres. La creación de un registro de la RLCA es necesaria en el futuro para un control más preciso y nuevas investigaciones.

Descriptores: reconstrucción del ligamento cruzado anterior; incidencia; sexo; grupos de edad.

\section{INTRODUCTION}

Musculoskeletal injuries are one of the major public health problems worldwide, causing a significant level of disability and suffering for individuals, as well as high burden to the health system and society?. Tear of the anterior cruciate ligament (ACL) of the knee is one of the most common injuries in sports medicine and orthopaedics fields, especially in young athletes who play multi-directional sports, such as soccer, basketball and handball².

There are commonly two ways to manage an ACL tear, ACLR or conservative treatment. However, for the young, active athlete ACLR offers more reliable restoration of knee stability and more predictable return to sports ${ }^{3,4}$. On the other hand, conservative approach is often reserved for lower-demand and older patients ${ }^{5}$.

In recent years, ACLR registries have been developed that provide great insight into the epidemiology of the surgery. Worldwide the incidence varies from 34 in Norway to 52 ACLR per 100,000 persons/year in Australia ${ }^{2,6}$. However, the incidence of ACLR in Brazil is currently unknown. Considering the large population of almost 205 million people and the high participation in sports with a high risk of ACL injury such as soccer and volleyball7, monitoring the incidence of ACLR is needed. Thus, the primary aim of this study is to report the overall incidence of ACLR in the Brazilian public health system over time and relative to sex and age. Considering the high participation of Brazilians in soccer and volleyball, we hypothesized that the incidence of ACLR would be similar to other countries. The secondary aim is to report on the hospital length of stay and cost related to $A C L R$ in Brazil.

\section{METHODS}

\section{Data source and participants}

We conducted a retrospective epidemiological study. Data were extracted using the free software TabWin (version 3.6b, DATASUS, Brazil) from the Health Informatics Department of the Brazilian Ministry of Health database, known as DATASUS. This database is used as an instrument for reimbursement by the Brazilian Unified Health System (BUHS) and comprises public, university and authorized hospitals (private hospitals, reimbursed per bed day by the public system). It contains information on medical procedures, diagnoses, type of admissions, demographic information and other reimbursement data ${ }^{8}$. Data entry is managed by cities and states as a standard procedure, with data related to the hospital admission authorization (HAA). Accordingly, this study evaluated all HAA records associated with ACLR, funded by the BUHS. It is currently not possible to identify if the same person had more than one procedure in the database, incidence rates are based on the number of procedures divided by the population. To identify all ACLR procedures conducted in the public health system in Brazil, we conducted a search through the registry selecting the code "0408050160 - Knee intra-articular ligament reconstruction (Anterior Cruciate)", from January 2008 to December 2014. We selected January 2008 as the earliest time period because specific ACLR data was not available prior to this date. Information related to the number of ACLR procedures, direct costs (sum of medical and hospital services) and length of hospital stay were extracted, as well as demographics including age and sex regarding the whole country.

\section{Ethics}

This public database provides data in a non-identifiable and generic format. Thus, this study was exempt from ethical approval according to our institution's policy.

\section{ACLR incidence calculation}

Overall incidence was defined as the total number of ACLR in the study period divided by the sum of the concerning population over the study period, multiplied by 100,000 year ${ }^{2,9,10}$, official population estimation was obtained from the Brazilian Institute of Geography and Statistics and used as the denominator for each year of reported ACLR events covered by the study. ACLR incidence stratified for age and sex was calculated relative to the total Brazilian population reported by each age and sex group. All incidences were expressed as the number of ACLR per 100,000 person/year.

\section{Data analysis}

Data were extracted from the database to an Excel spreadsheet. Analyses were performed using Excel for calculating the incidence while SPSS (version 22.0, SPSS Inc, Chicago, IL) was used through Linear Regression to perform the trend analysis for overall ACLR incidence, as well as sex and age incidence, besides the hospital length of stay's trend. ACLR Cost was defined as the sum of medical and hospital services. A level of $a=0.05$ was a priori set to determine statistical significance.

\section{RESULTS}

\section{ACLR incidence from 2008 to 2014}

During the period of seven years (2008-2014), there were 48,241 ACLR operations performed in the BUHS (Table 1). The overall population-based incidence was 2.59 in 2008 and increased by $64 \%$ to 3.49 per 100,000 person/year in $2014(p=0.005)$

\section{ACLR incidence relative to sex and age}

Males accounted for $82 \%$ of the procedures $(n=39,586)$ and females for the remaining $18 \%(n=8,655)$. The incidence of ACLR increased significantly over time for the total population $(p=0.005$, (Figure1). The increase for males was 56\% (from 4.44 in 2008 to 6.53 per 100,000 person/year in 2014, $p=0.01$ ), while for females it was $112 \%$ (from 0.77 in 2008 to 1.54 per 100,000 person/year in 2014, $p=0.001$ ). Considering male and females together those between 0-10 years-old accounted for less than $1 \%$ of the procedures, 11-20y for $11 \%, 21-30 y$ for $36 \%, 31-40 y$ for $30 \%, 41-50 y$ for $16 \%$ and $>51 y$ for $7 \%$ of the total number of surgeries. Trend analysis of the change in 
Table 1. Distribution by age and gender of ACLR and incidence from 2008 to 2014.

\begin{tabular}{|c|c|c|c|c|c|c|c|c|c|c|c|c|c|c|}
\hline & \multicolumn{2}{|c|}{2008} & \multicolumn{2}{|c|}{2009} & \multicolumn{2}{|c|}{2010} & \multicolumn{2}{|c|}{2011} & \multicolumn{2}{|c|}{2012} & \multicolumn{2}{|c|}{2013} & \multicolumn{2}{|c|}{2014} \\
\hline Overall & 4954 & 2,6 & 6411 & 3,3 & 6939 & 3,6 & 6820 & 3,5 & 7467 & 3,8 & 7527 & 3,7 & 8123 & 4,0 \\
\hline \multicolumn{15}{|l|}{ Age } \\
\hline \multicolumn{15}{|l|}{ Male } \\
\hline $11-20 y$ & 368 & 2,1 & 488 & 2,8 & 487 & 2,8 & 545 & 3,1 & 642 & 3,7 & 700 & 4,0 & 703 & 4,0 \\
\hline $21-30 y$ & 1674 & 9,6 & 2098 & 11,9 & 2260 & 12,8 & 2124 & 12,0 & 2292 & 13,0 & 2275 & 13,0 & 2486 & 14,3 \\
\hline $31-40 y$ & 1380 & 9,8 & 1769 & 12,3 & 1801 & 12,3 & 1789 & 12,0 & 1841 & 12,0 & 1824 & 11,6 & 1990 & 12,4 \\
\hline $0-10 y$ & 4 & 0,0 & 3 & 0,0 & 5 & 0,0 & 1 & 0,0 & 1 & 0,0 & 0 & 0,0 & 2 & 0,0 \\
\hline $11-20 y$ & 109 & 0,6 & 160 & 1,0 & 194 & 1,2 & 177 & 1,1 & 237 & 1,4 & 220 & 1,3 & 208 & 1,2 \\
\hline $21-30 y$ & 177 & 1,0 & 290 & 1,7 & 326 & 1,9 & 309 & 1,8 & 332 & 1,9 & 330 & 1,9 & 400 & 2,3 \\
\hline $31-40 y$ & 175 & 1,2 & 236 & 1,6 & 269 & 1,8 & 280 & 1,9 & 349 & 2,3 & 372 & 2,4 & 387 & 2,4 \\
\hline $41-50 y$ & 159 & 1,3 & 193 & 1,6 & 231 & 1,8 & 230 & 1,8 & 270 & 2,1 & 311 & 2,4 & 335 & 2,5 \\
\hline$>51$ & 122 & 0,7 & 157 & 0,8 & 192 & 1,0 & 193 & 1,0 & 233 & 1,1 & 229 & 1,1 & 247 & 1,1 \\
\hline
\end{tabular}

$\overline{\mathrm{ACLR}}=$ Anterior cruciate ligament reconstruction; Incidence per 100,000 person/year.

annual incidence showed a significant increase in all age groups in females (Figure 2), except those younger than 11 years old. On the other hand, in males there was an increase for the 11-20, 21-30 and 41-50 year old groups (Figure 3).

\section{Hospital length of stay and total cost}

The average length of stay over the 7 years was $2 \pm 0.23$ days of hospitalization. In 2008, the average was 2.4 days but it reduced to 1.8 days by $2014\left(R^{2}=0.883, p=0.002\right.$. The total cost for the whole period, after adjusted for inflation, was US\$56 million with a mean of US\$1,145 per ACLR. From 2008 to 2014, the total cost increased by 115\% (from US\$5 million in 2008 to 11 million in $2014 ; R^{2}=0.902, p=0.001$ ) while the total cost per surgery increased by $31 \%$ (from US\$1,067 in 2008 to US\$1,396 in $\left.2014 ; R^{2}=0.628, p=0.034\right)$. However, it appears that the majority of the increase in the cost per surgery occurred in the last two years (Figure 4).

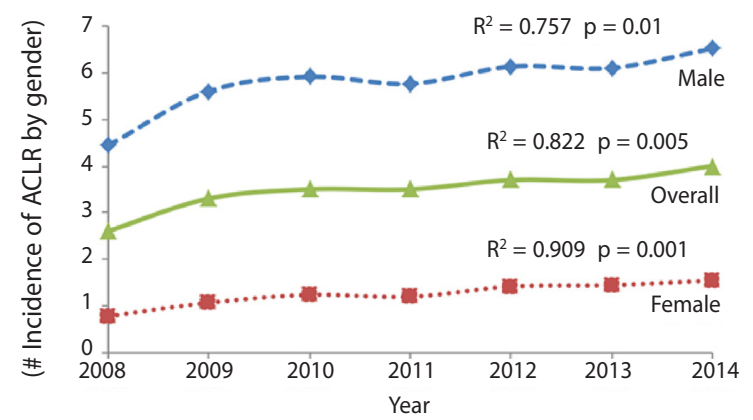

*ACLR (anterior cruciate ligament reconstruction)

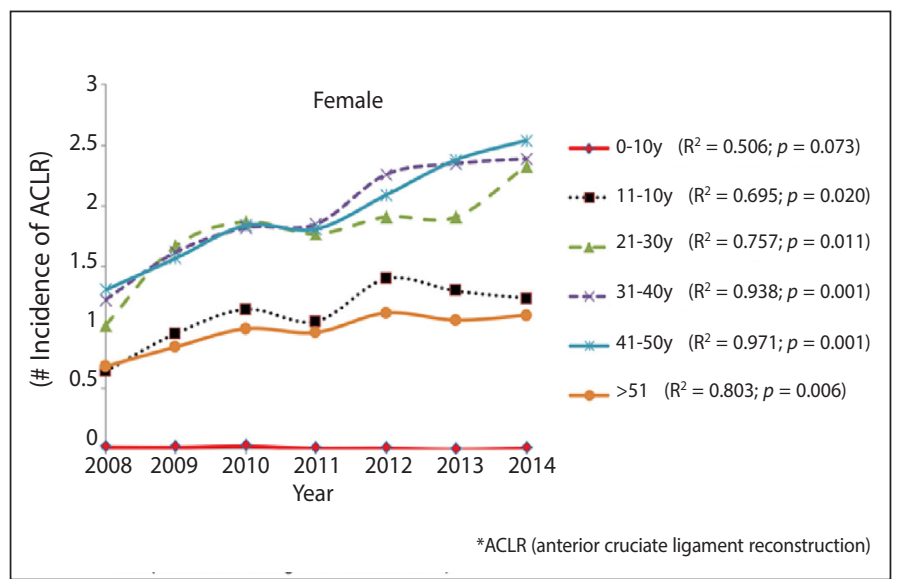

Figure 2. Tend of ACLR incidence in femele by age group.

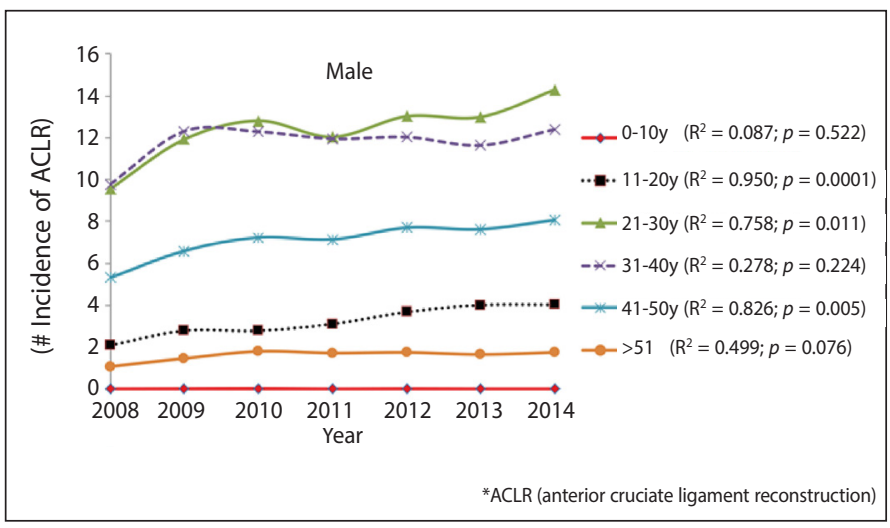

Figure 3. Trend of ACLR incidence in male by age group. 


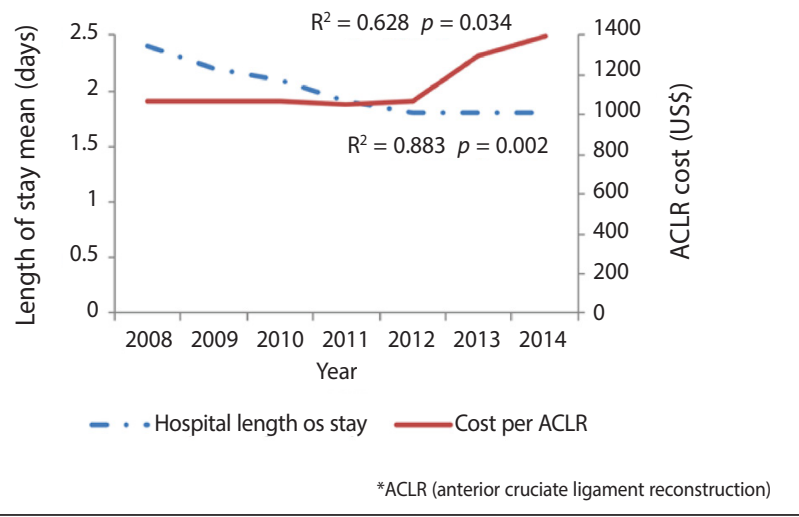

Figure 4. Trend of Hospital length of stay and ACLR cost per surgery.

\section{DISCUSSION}

This is the first study to systematically investigate the incidence, demographics and cost of ACLR in Brazil's public health system. It revealed several key findings that can be used to guide policy and health economics: a) overall, the incidence of ACLR in Brazil was a lot lower than in other countries; b) the incidence has been steadily increasing in recent years, c) males accounted for the vast majority of the procedures; however, the incidence has been increasing more among females d) hospital stay has decreased from 2008 to 2014; however it is still high in comparison with other countries, and e) the cost per ACLR increased by $31 \%$ with the majority of the increase happening in the last two years.

We expected the true incidence of ACLR in Brazil to be higher than identified in this study, particularly as soccer, a major recreational sport in Brazil, is associated with a high risk for ACL injury 11,12. However, the overall incidence of ACLR was low compared with reports from other countries. The ACLR incidence reported per 100,000 persons/year was 44 in the US in 2006', 52 in Australia from 2003-2008², 37 in New Zealand from 2000-2005'10, 34 in Norway in 2005-2006 ${ }^{6}$ and 38 in Denmark from 2005 to $2007^{11}$. The low incidence in Brazil which was more than 15 times lower than in other countries may be because this study did not capture ACLR performed in private hospitals or paid by private insurance; however, this is unlikely to be the sole explanation as only $25 \%$ of Brazilians have private insurance (National Agency of Supplementary Health Care; http://www.ans.gov.br/perfil-do-setor/dados-gerais). Another explanation and perhaps the most worrying would be the difficult access to the BUHS by those who injured their ACL as almost $10 \%$ of the Brazilian population that do not have a private insurance do not have access to the public health system as well ${ }^{13}$. Furthermore, the BUHS works with quotas, where each city has a finite number of procedures, exams, surgeries, so once these quotas are met all remaining procedures must be postponed to next year ${ }^{14}$. Thus, probably a considerable number of people with an ACL tear in Brazil may not have access to ACLR surgery or may be placed on lengthy waiting lists. Finally, it may be possible that conservative management is more commonly the recommended treatment for ACL tear in Brazil. But, conservative treatment for ACL is quite popular in Scandinavia, yet the ACLR rates are much higher than in Brazil. We, therefore, recommend that a national $A C L$ registry should be created in Brazil to more accurately identify the extent of the problem by capturing almost all ACLR.

The incidence of ACLR varied considerably between sex and age groups. The vast majority of procedures was performed in males which is consistent with the finding in the U.S. study even though the proportion of females having ACLR in the U.S. was a lot higher, 18\% in Brazil and $42 \%$ in the U.S. ${ }^{9}$, however the proportion of females having ACLR has been steadily increasing in both countries. An explanation for the higher increase in females may be related to higher participation in sports by females in recent years.

In the present study, those younger than 11 years old had a very low rate of ACLR. Due to differences in age group categorization between studies it is difficult to make a direct comparison. Nevertheless, this finding is consistent with a study conducted in Sweden which also showed that children aged below 10 years old account for less than $1 \%$ of total ACLR 4 . Maybe, this finding can be related with the fact that $A C L$ tear is a rare injury in children ${ }^{15,16}$ and generally surgeons prefer a conservative treatment for them due to the open growth plates that may be damaged during $A C L R^{17}$. Surgery between those with 11 to 20 years old presented a significant increase over time; the same findings were seen in Sweden and the U.S. and can be explained by an increased participation in competitive sports by a youth population 4,17 . In our study, people aged between 21 to 40 years accounted for 2/3 of the total ACLR, most likely because of the high activity levels and participation in sports ${ }^{9,18}$. So, it seems that in Brazil the ACLR incidence regarding to age and sex is following similar worldwide trends.

Even though, there was a decrease in the hospital length of stay over time, Brazilian hospital stay is still higher in comparison with other countries. In the U.S. in 1994, 43\% of ACLR were performed in outpatient ambulatory surgery centers, sometimes discharging the patient hours after the surgery. In 2006, this rate rose to $95 \%$ of all ACLR performed in the U.S. ${ }^{9}$ even though a systematic review on the topic does not currently exist, individual studies that compared inpatient and outpatient ACLR surgery did not find an advantage of inpatient procedures ${ }^{19-22}$. Moreover, a recent study ${ }^{23}$, demonstrated potential economic benefits when ACLR procedures are performed in outpatient environments. The total cost of ACLR over the period is substantial and can get worse due to an increasing incidence of ACLR in Brazil overtime. Thus, increasing the proportion of outpatient ACLR procedures may result in cost saving that can potentially free up funds for offering surgery to patients on the waiting list.

The total cost to the public health system increased from US\$5 million in 2008 to 11 million in 2014 due to the increase in the number of operations but also an increase in cost per surgery. The majority of the increased cost per surgery happened in the last two years (from US\$1,071 in 2012 to US\$1,396 in 2014; Figure 4). This increase is particularly concerning as if it continues it will lead to an even greater burden to the Brazilian health care system. It is important to note, however, that the cost per surgery is still low compared to other industrialized nations; in the U.S. the average cost of inpatient ACLR is over US\$30,00024. Comparing costs per surgery across nations is particularly challenging as the size of U.S. economy is very different of the Brazilian economy.

Whilst this is the first study to report incidence of ACLR in Brazil, some limitations need to be considered in light of these findings. By using this database, our results were limited only to procedures performed or paid by the BUHS. Accordingly, we could not capture ACLR procedures conducted under the private health system. Our study used data collected from an administrative database, thus data entry errors may have occurred.

\section{CONCLUSION}

The total incidence of ACLR in Brazil is lower compared to other countries but it is steadily increasing, especially among women. Additionally, ACLR in Brazil is associated with longer hospital stay than in other countries. Setting up an ACLR registry in Brazil would allow for a more comprehensive evaluation of cost and outcomes.

All authors have declared there is not any potential conflict of interests concerning this article. 
AUTORES' CONTRIBUTIONS: Each author contributed individually and significantly to the development of the manuscript. TJAL (0000-0001-7615-1540)* MS (0000$0002-5387-3986)^{*}$ and EP $(0000000283400303)^{*}$ contributed in the drafting of the manuscript, while TJAL performed the literature search and data acquisition. TJAL, MS and EP contributed to the intellectual concept of the study, evaluated the data of the statistical analysis and were responsible for the review of the manuscript. All authors contributed to the intellectual concept of the study. * Number ORCID (Open Researcher and Contributor ID).

\section{REFERENCES}

1. Mock C, Cherian MN. The global burden of musculoskeletal injuries: challenges and solutions. Clin Orthop Relat Res. 2008;466(10):2306-16.

2. Janssen KW, Orchard JW, Driscoll TR, van Mechelen W. High incidence and costs for anterior cruciate ligament reconstructions performed in Australia from 2003-2004 to 2007-2008: time for an anterior cruciate ligament register by Scandinavian model? Scand J Med Sci Sports. 2012;22(4):495-501.

3. Astur DC, Batista RF, Gustavo A, Cohen M. Trends in treatment of anterior cruciate ligament injuries of the knee in the public and private healthcare systems of Brazil. Sao Paulo Med J. 2013;131(4):257-63.

4. Nordenvall R, Bahmanyar S, Adami J, Stenros C, Wredmark T, Felländer-Tsai L. A population-based nationwide study of cruciate ligament injury in Sweden, 2001-2009: incidence, treatment, and sex differences. Am J Sports Med. 2012;40(8):1808-13.

5. Mather RC 3rd, Koenig L, Kocher MS, Dall TM, Gallo P, Scott DJ, et al. Societal and economic impact of anterior cruciate ligament tears. J Bone Joint Surg Am. 2013;95(19):1751-9.

6. Granan LP, Bahr R, Steindal K, Furnes O, Engebretsen L. Development of a national cruciate ligament surgery registry: the Norwegian National Knee Ligament Registry. Am J Sports Med. 2008;36(2):308-15

7. Costa LP, Bitencourt V, Nogueira L, Miragaya AM, Matsudo V, Noé, et al. Scenario of the general trends of sports and physical activities in Brazil. Atlas of Sport in Brazil. Rio de Janeiro: CONFEF; 2006.

8. de Mello PS, Almeida RM, Pereira WC. A computerised information system for the analysis of hospital admission flow and characteristics. Int J Med Inform. 2001;61(1):11-20.

9. Mall NA, Chalmers PN, Moric M, Tanaka MJ, Cole BJ, Bach BR Jr, et al. Incidence and trends of anterior cruciate ligament reconstruction in the United States. Am J Sports Med. 2014;42(10):2363-70.

10. Gianotti SM, Marshall SW, Hume PA, Bunt L. Incidence of anterior cruciate ligament injury and other knee ligament injuries: a national population-based study. J Sci Med Sport. 2009;12(6):622-7.

11. Lind $\mathrm{M}$, Menhert F, Pedersen $A B$. The first results from the Danish $A C L$ reconstruction registry: epidemiologic and 2 year follow-up results from 5,818 knee ligament reconstructions. Knee Surg Sports Traumatol Arthrosc. 2009;17(2):117-24.

12. Mei Y, Ao YF, Wang JQ, Ma Y, Zhang X, Wang JN, et al. Clinical characteristics of 4355 patients with anterior cruciate ligament injury. Chin Med J (Engl). 2013 Dec;126(23):4487-92

13. Silva PLB. Serviços de Saúde: o dilema do SUS na nova década. São Paulo Perspectiva. 2003;17(1):69-85.
14. Viegas SM, Penna CM. The Brazilian Unified Health System (SUS) is universal, but quotas are the norm. Cien Saude Colet. 2013;18(1):181-90.

15. Pappas E, Zazulak BT, Yard EE, Hewett TE. The epidemiology of pediatric basketball injuries presenting to us emergency departments: 2000-2006. Sports Health. 2011;3(4):331-5.

16. Shea KG, Pfeiffer R, Wang JH, Curtin M, Apel PJ. Anterior cruciate ligament injury in pediatric and adolescent soccer players: an analysis of insurance data. J Pediatr Orthop. 2004;24(6):623-8.

17. Dodwell ER, Lamont LE, Green DW, Pan TJ, Marx RG, Lyman S. 20 years of pediatric anterior cruciate ligament reconstruction in New York State. Am J Sports Med. 2014;42(3):675-80.

18. Barrett G, Stokes D, White M. Anterior cruciate ligament reconstruction in patients older than 40 years: allograft versus autograft patellar tendon. Am J Sports Med. 2005;33(10):1505-12.

19. Valkering KP, van Bergen CJ, Buijze GA, Nagel PH, Tuinebreijer WE, Breederveld RS. Pain experience and functional outcome of inpatient versus outpatient anterior cruciate ligament reconstruction, an equivalence randomized controlled trial with 12 months follow-up. Knee. 2015;22(2):111-6.

20. Lefevre N, Klouche S, de Pamphilis O, Devaux C, Herman S, Bohu Y. Postoperative discomfort after outpatient anterior cruciate ligament reconstruction: a prospective comparative study. Orthop Traumatol Surg Res. 2015;101(2):163-6.

21. Andrés-Cano P, Godino M, Vides M, Guerado E. Postoperative complications of anterio cruciate ligament reconstruction after ambulatory surgery. Rev Esp Cir Ortop Traumatol. 2015;59(3):157-64

22. Astur DC, Navarro PGR, Fonseca LF, Arliani GG, Aleluia V, Veronese C, et al. Why do patients undergoing anterior cruciate ligament reconstruction in Brazil stay in hospital for longer periods than in other countries? Prospective evaluation of 30 patients and presentation of possible discharge criteria. Rev Bras Ortop. 2013:48(4):336-40.

23. Saltzman BM, Cvetanovich GL, Nwachukwu BU, Mall NA, Bush-Joseph CA, et al. Economic Analyses in Anterior Cruciate Ligament Reconstruction: A Qualitative and Systematic Review. Am J Sports Med. 2016;44(5):1329-35

24. Bates NA, McPherson AL, Rao MB, Myer GD, Hewett TE. Characteristics of inpatient anterior cruciate ligament reconstructions and concomitant injuries. Knee Surg Sports Traumatol Arthrosc. 2014 Dec 16. [Epub ahead of print]. 